\title{
THE SITES OF THE EARLY NOMADS ON THE NORTH-EAST PERIPHERY OF THE SARMATIAN WORLD ${ }^{1}$
}

\author{
Alexander D. Tairov \\ South Ural State University, Chelyabinsk, Russian Federation
}

\begin{abstract}
The paper publishes new materials of the early Sarmatian time from the North-East periphery of the Sarmatian World - the Southern forest-steppe and steppe zones of the Trans-Ural region within the bounds of the modern Chelyabinsk region. The territory of the Southern forest-steppe is represented by the materials of the ruined burial, which is situated on the shore of the lake Smolino within the bounds of Chelyabinsk. It is dated by the early $4^{\text {th }}$ century BC. There are three accidental finds from this region: iron daggers as well. The daggers with curved bar-shaped pommels and arcuate cross-guards are classified as daggers of "transitional type" and are dated by the $4^{\text {th }}$ century BC. The third dagger with a semicircular pommel and a straight cross-guard is included in the group of classical Prokhorovka daggers and is dated the $3^{\text {rd }}-2^{\text {nd }}$ centuries BC.

This paper presents the materials of two peculiar burial complexes from the steppe zone of the Southern Trans-Urals. The burial near Mogutovka village is the only one burial (without a barrow) of the early Sarmatian time, which was investigated in the Southern Trans-Ural region. It is situated on the first terrace above the floodplain of the Kamysty-Ayat river. The localization of the burial is not typical for the sites of the early Trans-Ural nomads of the $1^{\text {st }}$ millennium BC. The early Sarmatian burial of the $3^{\text {rd }}-2^{\text {nd }}$ centuries BC was excavated in Druzhinskiy burial site. It was made in the burial pit, which combines signs of a catacomb and an alcove. A child buried here was dressed in a shirt, whose collar and sleeves were decorated with beading.

Publishing materials will help to expand the point of view on burial rites and material culture of the early Trans-Ural nomads of the early Sarmatian time, which exists in scientific literature.
\end{abstract}

Key words: the Southern Trans-Urals, the early Sarmatian time, burial rite, armament, early Nomads.

Citation. Tairov A.D., 2019. The Sites of the Early Nomads on the North-East Periphery of the Sarmatian World. The Lower Volga Archaeological Bulletin, vol. 18, no. 1, pp. 97-109. (in Russian). DOI: https://doi.org/ 10.15688/nav.jvolsu.2019.1.8

УДК 903.54

Дата поступления статьи: 26.01.2019

ББК Т442(2Р36)

Дата принятия статьи: 01.03.2019

\section{ПАМЯТНИКИ РАННИХ КОЧЕВНИКОВ НА СЕВЕРО-ВОСТОЧНОЙ ПЕРИФЕРИИ САРМАТСКОГО МИРА ${ }^{1}$}

\author{
Александр Дмитриевич Таиров \\ Южно-Уральский государственный университет, г. Челябинск, Российская Федерация
}

\begin{abstract}
Аннотация. Статья посвящена публикации новых материалов раннесарматского времени с территории северо-восточной периферии сарматского мира - южной лесостепной и степной зон Зауралья в пределах современной Челябинской области. Территория южной лесостепи представлена материалами разрушенного погребения первой половины IV в. до н.э., обнаруженного на берегу озера Смолино в черте города Челябинск. Случайные находки из этого региона представлены тремя железными кинжалами. Кинжалы с изогнутым брусковидным навершием и дуговидным перекрестьем отнесены автором к кинжалам «переходного типа» и датированы IV в. до н.э. Третий кинжал, с полукольцевым навершием и прямым перекрестьем, включен в группу классических прохоровских кинжалов и датирован III-II вв. до н.э.

Из степной зоны Зауралья публикуются материалы двух своеобразных погребальных комплексов. Поస्త్ гребение у села Могутовка (начало IV в. до н.э.) является единственным исследованным в Южном Зауралье (?) грунтовым бескурганным захоронением раннесарматского времени. Оно находилось на первой надпой-
\end{abstract}


менной террасе реки Камысты-Аят, что совершенно не характерно для памятников ранних кочевников Южного Зауралья I тыс. до н.э. Раннесарматское погребение III-II вв. до н.э., исследованное в могильнике Дружинский, совершено в могильной яме, которая сочетает в себе признаки катакомбы и подбоя. Захороненный здесь ребенок был одет в рубаху, ворот и длинные рукава которой были обшиты бусами и бисером.

Публикуемые материалы расширяют существующие в научной литературе представления о погребальном обряде и материальной культуре ранних кочевников Южного Зауралья раннесарматского времени.

Ключевые слова: Южное Зауралье, раннесарматское время, погребальный обряд, предметы вооружения, ранние кочевники.

Цитирование. Таиров А. Д., 2019. Памятники ранних кочевников на северо-восточной периферии сарматского мира // Нижневолжский археологический вестник. Т. 18, № 1. С. 97-109. DOI: https://doi.org/10.15688/ nav.jvolsu.2019.1.8

Ранние кочевники северо-восточной периферии сарматского мира обитали в южной лесостепной зоне Зауралья, в междуречье Уя на юге и Миасса на севере, особое место в которой занимают крайние ее северные рубежи район Челябинска и долина реки Миасс, и в степях Зауралья к югу от реки Уй. Как южная лесостепь, так и степь Южного Зауралья, составляющие единое историко-культурное пространство, были прочно освоены ими уже в начале эпохи железа. Протекавшие здесь этнокультурные процессы сыграли значительную роль в истории всего сарматского мира.

Предлагаемая статья посвящена характеристике погребальных комплексов и случайных находок раннесарматского времени этого региона, уже частично знакомых специалистам по рисункам в разных изданиях, но до сих пор полностью не опубликованных.

Район Челябинска в связи с его географическим положением на границе южной и северной лесостепи, в зоне контактов степных и лесостепных племен, издавна привлекал внимание исследователей, занимающихся изучением культур эпохи бронзы и раннего железа. В начале XX века «в районе не свыше 20 верст во все стороны от города Челябинск» чиновником переселенческого управления Н.К. Минко было обнаружено «по предварительному подсчету свыше 1000 курганов». В период с 1906 по 1909 г. им исследовано около 90 курганов, содержащих погребения от эпохи бронзы до позднего средневековья [Мошкова, 1969, c. 138-139].

Рассмотрев материалы курганов раннего железного века, раскопанных Н.К. Минко в окрестностях Челябинска, К.Ф. Смирнов и М.Г. Мошкова разбили их на две хронологические группы - конец VII - V в. до н.э. и IVIII вв. до н.э. [Смирнов, 1964, с. 57, 68, $153-$
154, 162-163; Мошкова, 1969, с. 140]. В отличие от К.Ф. Смирнова, включившего Челябинские курганы в группу савромато-сарматских памятников [Смирнов, 1964, с. 57, 68, 192], М.Г. Мошкова совершенно справедливо подчеркивала их смешанный характер, отражающий процессы взаимодействия кочевников степи и полукочевого населения лесостепи Южного Зауралья [Мошкова, 1969, с. 146-147].

Осенью 1979 г. в археологическую лабораторию Челябинского государственного университета поступили материалы разрушенного при строительстве водопровода погребения на территории профтехучилища № 123 (ул. Машиностроителей, 29), находящегося на северном берегу озера Смолино [Хабдулина, Малютина, Виноградов, 1980; Таиров, 1987]. Обряд погребения зафиксировать не удалось. Сопровождающий инвентарь представлен железными мечом, удилами и псалиями, шестью бронзовыми наконечниками стрел и бронзовой бляшкой (рис. 1).

Сильно коррозированный, сломанный короткий меч имеет слабо изогнутое брусковидное навершие, округлое в поперечном разрезе (рис. 1,1). Дуговидное перекрестье, скованное из двух пластин, расслоилось и сохранилось только с одной стороны клинка. Короткая рукоять подпрямоугольной в сечении формы имеет в середине одной из сторон узкий продольный желобок. Клинок в сечении линзовидный, со следами дерева на его поверхности. Длина: меча - 47 см, рукояти - 7,5 см, перекрестья - 7,8 см; ширина клинка 6,5 см.

Описываемый меч относится к типу VI.2 по классификации К. Ф. Смирнова [Смирнов, 1961, с. 26-27] или типу IV.2 по М. Г. Мошковой [Мошкова, 1963, с. 33, табл. 18,7-8], за которыми в археологической литературе закрепился термин «переходного типа». На Юж- 
ном Урале, по мнению большинства исследователей, они появляются в конце $\mathrm{V}$ в. до н.э. или на рубеже V-IV вв. до н.э., широко распространяются в IV в. до н.э. и существуют, вероятно, до первой четверти III в. до н.э. [Смирнов, 1961, с. 24, 26; Мошкова, 1963, с. 33; Хабдулина, Малютина, 1982, с. 79; Исмагилов, 2001, с. 119; Васильев, 2004, с. 169; Васильев, Сиротин, 2004, с. 180; Денисов, 2018, c. 377-378].

Как представляется, первые образцы мечей и кинжалов «переходного типа» - с прямым или слегка изогнутым брусковидным навершием, дуговидным или сломанным под тупым углом перекрестьем (типа IV.2 по М.Г. Мошковой), появляются в Южном Зауралье во второй половине $\mathrm{V}$ в. до н.э. Исходной территорией распространения клинкового оружия со сломанным под тупым углом и дуговидным перекрестьем является, на наш взгляд, Северный и Северо-Западный Китай и Западная Монголия. Среди разнообразных перекрестий бронзовых кинжалов из этого региона есть перекрестья в виде бруска, сломанного под прямым углом, дуговидные с приподнятыми окончаниями, узкие бабочковидные, приближающиеся по форме к сломанному под тупым углом, а также сломанные под тупым углом. Датируются они, как правило, в пределах VII-V вв. до н.э. [Таиров, 2016, с. 333-335, 339]. На Южном Урале происходит окончательное оформление клинкового оружия «переходного типа». А уже отсюда оно распространяется далее на запад степной Евразии [Глебов, Житников, 2008, с. 104; Белицкий, 2013, с. 232; Скрипкин, Ким, 2013, с. 276; Соколов, 2013, с. 286].

Появление на Южном Урале, прежде всего в Южном Зауралье, образцов клинкового оружия со сломанным под тупым углом или дуговидным перекрестьем привело, на наш взгляд, к возникновению гибридных форм мечей и кинжалов. В них сочетаются навершия, характерные для предшествующего времени (широкие брусковидные, антенные, волютообразные, когтевидные и т. п.), и перекрестья, соединяющие в себе признаки бабочковидных или подтреугольных и сломанных под тупым углом или дуговидных - узкие бабочковидные или крыльевидные. Существовали они достаточно короткое время, и абсолютное большинство их не выходит за рамки $V$ в. до н.э., и датируются они, по нашему мнению, второй половиной этого столетия [Таиров, 2016, с. 340].

Наконечники стрел представлены бронзовыми втульчатыми трехлопастными (рис. 1,2,3,5-7), со сводчатой головкой и выступающей втулкой, с гранями, обрезанными под прямым углом к втулке или заканчивающимися длинными шипами (5 экз.), - тип A.II.6 по классификации К.Ф. Смирнова [Смирнов, 1961, c. 46-48]. Длина их 2,1-2,9 см, втулки короткие, составляющие 1/4-1/3 общей длины. Один наконечник трехгранный (рис. 1,4 ), сводчатой формы, с внутренней втулкой и трехгранным острием, переходящим в грани с опущенными вниз шипами, с продольными ложками, отделяющими лопасти от втулки, - тип А.ІІІ.15А по К.Ф. Смирнову [Смирнов, 1961, с. 56-57].

Наконечники типа А.II.6 употреблялись кочевниками Южного Урала с конца VII по II в. до н.э., но наиболее широко использовались в VI-IV вв. до н.э.; наконечники типа A.III.15A известны в конце VI - V в. до н.э. [Смирнов, 1961, с. 46-47, 56-57].

Удила железные двусоставные, с загнутыми в петли концами, с прямоугольными в сечении стержнями длиной 8,0 см и 10,3 см (рис. 1,9).

Железные двудырчатые псалии S-видной формы с восьмеркообразным утолщением в середине, округлой шишечкой на одном конце стержня и утолщением в виде стилизованного копыта лошади на другом (рис. 1,10). Длина псалиев, сломанных на уровне одного из отверстий, около 17 см. Стержни обоих псалиев прямоугольные в поперечном сечении. Псалии этого типа были особенно характерны, по мнению К.Ф. Смирнова, для V в. до н.э. [Смирнов, 1961, с. 84].

Бронзовая круглая бляшка диаметром 2,4 см, полусферической формы, с отверстием диаметром 0,5 см в центре, имеет с внутренней стороны по обе стороны от отверстия два обломанных шпенька диаметром 0,4 см (рис. 1,8).

Исходя из формы меча, наконечников стрел и псалиев, погребение на территории профтехучилища следует датировать первой половиной IV в. до н.э. Оно органически дополняет Челябинскую группу курганов и, таким образом, входит в число самых северных памятников прохоровской культуры. 
K IV в. до н.э. могут быть отнесены и два железных кинжала из фондов Музея имени кинорежиссера С.А. Герасимова в селе Кундравы Чебаркульского района Челябинской области. Кинжал, найденный на пашне близ села Боровое, целый, а у кинжала из окрестностей села Кундравы утрачена большая часть клинка (рис. 2,1,2). У обоих кинжалов узкое слабоизогнутое брусковидное навершие (в виде слегка изогнутого дрота - по Р.Б. Исмагилову) и дуговидное перекрестье с несколько расширяющимися концами, скованное из двух пластин. У целого кинжала (рис. 2,1) узкая подпрямоугольная в сечении рукоять, отделенная от навершия узким валиком. Его ромбический в сечении клинок в форме вытянутого треугольника имеет по центру обеих сторон слабо выраженную нервюру в виде валика. У второго кинжала (рис. 2,2) рукоять широкая, овально-подпрямоугольная в сечении. Рукоять отделена от навершия нешироким валиком. Клинок в сечении линзовидный. Оба кинжала имеют многочисленные аналогии среди мечей и кинжалов IV в. до н.э. [Мошкова, 1963, табл. 18,11,13; Обыденнов, Савельев, 1994, рис. 1,1-3; Исмагилов, 2001, c. 119, табл. III,20,25-28; Васильев, 2001, рис. 7; 9; Васильев, 2004, рис. 1; Скрипкин, Ким, 2013, рис. 1,1-5].

К более позднему времени относится железный кинжал (рис. 2,3), обнаруженный на пашне в окрестностях с. Дубровка Красноармейского района [Хабдулина, Малютина, Виноградов, 1980]. Кинжал хорошей сохранности, длиной 36,5 см, имеет узкое прямое перекрестье, по длине превышающее ширину клинка. Навершие его сделано в виде полукольца из круглого в сечении дрота. Узкая ромбическая в сечении рукоять имеет длину 8,5 см и ширину грани 1,3 см. Обоюдоострый клинок, линзовидный в разрезе, в верхней части по центру оформлен продольным желобком.

Дубровский кинжал, хотя и достаточно своеобразный по сочетанию полукольцевого навершия и прямого перекрестья, может быть включен в группу классических прохоровских мечей типа V.2 по классификации М.Г. Мошковой - мечи и кинжалы с серповидным или прямым навершием и прямым перекрестьем, единичные экземпляры которых появляются в погребениях IV в. до н.э., однако ведущей формой они становятся лишь с рубежа IVIII вв. до н.э. и господствуют до конца прохоровского времени [Мошкова, 1963, с. 34, табл. 18,16,17,20-22,25; 19,1,2,9-19]. По форме полукруглого навершия и прямого перекрестья кинжал из Дубровки наиболее близок кинжалу из Салихово и акинаку из Стерлитамака, включенным Р.Б. Исмагиловым в группу мечей и кинжалов раннесарматского времени с серповидным или рожковидным навершием и прямым перекрестьем [Исмагилов, 2001, с. 119, табл. V,47; IX,84]. Очевидно, что дубровский кинжал вряд ли относится к числу ранних, поэтому наиболее вероятным временем его изготовления может быть III-ІІ в. до н.э.

В южной подзоне Зауралья внимание привлекают два своеобразных погребальных комплекса - у сел Могутовка и Дружное.

В 1988 г. в результате подмыва первой надпойменной террасы левого берега реки Камысты-Аят близ с. Могутовка Брединского района Челябинской области обнажились кости человека. Могила была частично раскопана местными жителями: из нее извлекли костяк погребенного и большое количество фрагментов керамики от одного сосуда (рис. 3,3 ). Доследование могильной ямы было осуществлено А.Г. Гаврилюком в этом же году. Могильная яма на уровне -120 см от современной дневной поверхности имела форму вытянутого овала размерами $1,1 \times 2,6$ м, ориентированного почти по линии ССВ-ЮЮЗ (рис. 3,1). Погребальная камера находилась у западной стенки входной ямы. На уровне - 150 см она имела форму сильно вытянутого овала размерами $0,4 \times 1,8$ м, ориентированного почти по линии CЮ. Северо-западный угол камеры находился в неглубоком подбое под стенку входной ямы. На дне северной части погребальной камеры обнаружена кость голени человека, а у западной ее стенки на уровне -170 см найдены бронзовые наконечники стрел, лежащие кучкой (рис. 3,1,2). Судя по описанию захоронения местными жителями и сохранившейся в камере кости ноги, погребенный был уложен на спину в вытянутом положении, головой на юг. Как входная яма, так и погребальная камера были заполнены землей. Никаких следов надмогильного сооружения, несмотря на неповреж- 
денность береговой полосы, не зафиксировано. Данное обстоятельство позволяет предполагать, что перед нами остатки не курганного, а грунтового погребения.

Набор наконечников стрел из этого захоронения (рис. 3,2), где присутствуют экземпляры со сводчатой головкой, не позволяют датировать его временем позднее IV в. до н.э. C рубежа IV-III вв. до н.э. в прохоровских погребениях почти безраздельно господствуют стройные, вытянутые наконечники с треугольной головкой правильной формы [Мошкова, 1963, с. 31]. В то же время размеры и форма головок (узкие, приближающиеся к треугольным) наконечников типа A.II.6A, A.II.6Г (со сводчатой головкой и выступающей втулкой) и А.II.12 (с внутренней втулкой, опущенными ниже втулки шипами и сводчатой головкой) по классификации К.Ф. Смирнова не позволяют датировать погребение ранее конца V в. до н.э. В IV в. до н. э. широко распространяются крупные наконечники типа A.II.13 (с внутренней втулкой, опущенными ниже втулки шипами и треугольной головкой), в ІІІ в. до н.э. они уже по преимуществу мелкие. K IV в. до н.э. относятся и самые поздние наконечники типа A.II.8 [Смирнов, 1961, с. 46-48, 50-51, 5455]. Таким образом, комплекс наконечников стрел позволяет, на наш взгляд, датировать могутовское погребение IV в. до н.э., скорее его началом. Не противоречит такой датировке и сосуд, стоявший в головах (рис. 3,3 ). Он плоскодонный, приземистый, с резко раздутым, почти биконическим, туловом и трубчатым носиком-сливом, по плечикам орнаментирован резными петлями.

Могильник Дружинский находится в 7 км к юго-западу от села Дружное Варненского района Челябинской области. Занимает площадку на вершине возвышенности, господствующей над окружающей местностью и находящейся в 2,5 км к востоку от правого берега реки Тогузак. С юга и севера площадку памятника ограничивают заболоченные впадины, поросшие кустарником. Памятник состоял из семи курганов различной величины и грунтового сооружения, едва фиксируемого на поверхности. В полевом сезоне 1986 г. исследованы пять курганов и грунтовое сооружение [Боталов, 1986], давшие в основном материалы гунно-сарматского времени [Боталов, Гуцалов, 2000, с. 44-47, рис. 12, 13].

К сарматскому времени относится лишь погребение в яме 2 кургана 2, находящегося на северной окраине могильника. Земляная насыпь кургана в плане имела овальную форму, вытянутую по линии В-3, размеры $26 \times 28$ м и высоту 1,5 м. Центр насыпи прорезали два последовательных грабительских вкопа, полностью уничтоживших центральную часть подкурганной площадки. Никаких находок, за исключением нескольких фрагментов от сосудов, изготовленных на гончарном круге, ни в центре кургана, ни в его насыпи не обнаружено.

Яма 2 находилась под восточной полой кургана, в 11 м от его центра. На уровне -45 см (при раскопках кургана за 0 была принята точка на современной поверхности в 21 м к Ю3 от края его насыпи) она в плане имела овальную форму, размеры $0,7 \times 0,95$ м, ориентировку по линии С-Ю с небольшим отклонением (рис. 4,1 ). Заполнение состояло из коричневого суглинка. Между заполнением ямы и материком по всему периметру отмечалась тонкая (1-2 см) гумусная прослойка. При вскрытии ямы на глубине 60 см встречены обломки железного стерженька очень плохой сохранности, не позволяющей восстановить его точные размеры и форму. Очертания могильной ямы постепенно сдвигались к северу, несколько сокращались ее размеры, изменялась и форма. На уровне - 120 см (1,0 м от уровня материка) яма приобрела трапециевидную со скругленными углами форму, с узкой северной и широкой южной стенками. Размеры ее $0,5-0,7 \times 0,7$ м. Дальнейшее вскрытие ямы показало, что перед нами катакомба достаточно оригинальной конструкции (рис. 4,1-3). Ее наклонная входная яма глубиной 0,9 м, идущая с юга на север (угол наклона южной стенки около $45^{\circ}$, северной - около $55^{\circ}$ ), посредством уступа высотой 0,25 м переходила в предкамерное пространство. Ширина предкамеры у входной ямы 0,7 м, в средней части 0,6 м, а у северной стенки - 0,3 м. Длина ее 1,15 м, высота в северной части около $30 \mathrm{~cm}$. Дно предкамеры ровное, слегка наклонное с юга на север и с запада на восток. В восточной стенке предкамеры, параллельно ее длинной оси, вырублена погребальная камера дли- 
ной 0,85 м и шириной $0,25-0,3$ м. Дно ее корытообразное, наклонное с юга на север. Максимальная глубина дна от уровня материка 1,28 м (уровень -148 см от условного 0). Высота камеры, судя по смещению прослоек в материковом грунте, не превышала 0,3 м. На дне входной ямы, предкамеры и погребальной камеры отмечалась тонкая прослойка гумусированного суглинка.

На дне погребальной камеры расчищено захоронение ребенка. Погребенный был уложен вытянуто на спине, руки вдоль тулова, головой на юг, лицом на СBВ (рис. 4,1). На запястьях обеих рук лежали низки бус и бисера, которыми, вероятно, были обшиты рукава рубахи (рис. 4,5,6). На груди погребенного также обнаружена низка бус черного и зеленого цвета, которыми, судя по расположению, был обшит треугольный вырез рубахи (рис. 4,4).

Слева от ног погребенного, от уровня таза до уровня ступней, на границе камеры и предкамеры находился жертвенный комплекс, состовший из керамического сосуда, железного ножичка, костей барана (рис. 4,1). Сосуд лежал на боку у северной стенки предкамеры, горловина его была направлена в сторону камеры. Южнее сосуда находилась трубчатая кость барана, еще южнее, по одной линии с костью, лежала баранья лопатка, а под ней крупная кость с эпифизом. Чуть восточнее костей барана расчищен небольшой железный ножичек, лежавший острием на север.

Сосуд (рис. 4,9) круглодонный, тонкостенный неорнаментированный грушевидной формы. Шейка прямая, слегка отогнутая. Венчик округлый, оттянутый наружу. Обжиг хороший, черепок в изломе черный. Внешняя поверхность серная, со следами лощения. В тесте примесь песка и шамота. На внутренней поверхности сосуда - следы нагара. Высота сосуда $-16,5$ см, диаметр тулова $-16,5$ см, диаметр шейки у тулова - 8,0 см, диаметр венчика $-8,4$ см.

Круглодонные сосуды с грушевидным туловом на Южном Урале появляются еще в IV в. до н.э. Для них характерны не очень высокое прямое или воронкообразное горло и орнамент, нанесенный от горла по плечикам. По наблюдению М.Г. Мошковой, «в III-II вв. до н.э. облик их несколько изменяется - не столь ярко выражено горло, нет массивного дна и орнамент обычно отсутствует» [Мошкова, 1963, с. 27]. Исходя из этого, дружинский сосуд по своей форме, отсутствию массивного дна и орнамента входит в группу сосудов III-II вв. до н.э. Он также может быть сопоставлен с некоторыми усуньскими грушевидными кувшинами с округлым, слегка уплощенным, дном III-II вв. до н.э. [Акишев, Кушаев, 1963, табл. VI,4,7].

Ножичек железный (рис. 4,7), с прямым лезвием и горбатой спинкой, кончик лезвия обломан. Рукоять не выделена, но хорошо фиксируется по остаткам дерева. Длина изделия -9,2 см, максимальная ширина $-1,1 \mathrm{~cm}$, максимальная толщина треугольного в сечении лезвия $-0,3$ см. Толщина подпрямоугольной в сечении рукояти до $0,3 \mathrm{~cm}$, длина ее 3,7 см, ширина ножа на конце рукояти $-0,7 \mathrm{~cm}$. Ножи такой формы более характерны для раннесарматских комплексов III-II вв. до н.э. [Мошкова, 1963, с. 38].

Целых бусин 138 штук, из которых 47 находилось на запястье левой руки, 55 - на запястье правой руки, 36 - на груди (рис. 4,8 ). Среди бус одна трехчленная из прозрачного стекла с внутренней позолотой (рис. 4,8ю), одна стеклянная ребристая с внутренней позолотой (рис. $4,8 u$ ), одна темно-коричневая пастовая цилиндрическая двухчленная (рис. $4,8 x$ ), одна усечено-биконическая голубой пасты (рис. 4,8y), одна усечено-коническая серо-голубая пастовая (рис. $4,8 \phi)$, одна белая бочковидная (рис. $4,8 \mathrm{~m}$ ) и шесть голубых бочковидных и цилиндрических (рис. 4,8ч,8w) пастовых бисеринок, одна цилиндрическая стеклянная бусина светло-коричневого цвета с внутренней прокладкой (риc. 4,8 я), одна цилиндрическая светло-фиолетового (рис. $4,8 b l$ ) непрозрачного стекла, одна цилиндрическая зеленого (рис. $4,8 л$ ) и одна цилиндрическая голубовато-зеленого (рис. 4,8 ) стекла; усечено-конический и бочковидный гагатовый бисер (рис. 4,82-u), найденный только на груди погребенного. Однако большинство составляют небольшие бусины бочковидной или цилиндрической формы голубого стекла (рис. $4,8 a-8,8 \kappa, 8 \mu-m, 8 \ni)-$ их 92 штуки. Диаметр бус и бисера колеблется в пределах от 0,25 см до 0,6 см.

Впервые мелкие гагатовые бусы и бисер появляются в погребениях Южного Ура- 
ла в IV в. до н.э. [Смирнов, 1964, с. 149], но широко распространяются и становятся одними из наиболее излюбленных с рубежа IVIII вв. до н.э. [Мошкова, 1963, с. 45]. Гагатовый бисер из дружинского погребения аналогичен типам 8а, 8г, 9а гагатовых бус Северного Причерноморья [Алексеева, 1978, с. 12]. Здесь они, особенно маленьких размеров, известны в эллинистическое время (III-II вв. до н.э.), но чаще всего встречается в комплекcax I-II вв. н.э. С рубежа IV-III вв. до н.э. у южноуральских кочевников широко распространяются мелкие биконические и битрапецоидные бусы и бисер из синего полупрозрачного и непрозрачного стекла [Смирнов, 1964, c. $150 ; 1975$, рис. 31$]$. С этого же времени начинается и широкое распространение бус с внутренней позолотой, которые уже в III-ІІ вв. до н.э. занимают второе место после гагатовых по количеству в прохоровских погребениях [Мошкова, 1963, с. 45].

Таким образом, набор бус и бисер позволяют датировать дружинское погребение рубежом IV-III - II в. до н.э. Но некоторые данные позволяют сузить дату до III-II вв. до н.э., скорее даже до второй половины этого периода. Так, здесь найдена ребристая бусина (тип 10 по Е.М. Алексеевой) (рис. 4,8u), которые впервые появляются как на Южном Урале, так и в Северном Причерноморье в IIIII вв. до н.э. [Мошкова, 1963, с. 45; Алексеева, 1978, с. 31]. Не противоречит такой датировке ни погребальный обряд, ни остальной инвентарь.

Возможны два варианта соотношения дружинского погребения 2 с курганом: погребение впущено в уже расплывшуюся насыпь или, что представляется более вероятным, погребение совершено в могильной яме, вырытой у подножия кургана.

Публикуемые материалы расширяют представления о погребальном обряде и материальной культуре ранних кочевников Южного Зауралья раннесарматского времени.

\section{Параметры кинжалов.}

1. Кинжал из окрестностей с. Боро$\boldsymbol{в о е ~ ( р и с . ~ 2 , 1 ) . ~ О б щ а я ~ д л и н а ~} 39$ см. Навершие: длина $-6,4$ см, ширина до 0,6 см, толщина до
1,2 см. Валик: длина - 1,46 см, ширина 0,12 см. Рукоять: длина 7,2 см; ширина: у перекрестья - 2,0 см, у навершия - 1,2 см; толщина: у перекрестья - 1,3 см, у навершия 0,9 см. Перекрестье: длина 7,4 см; ширина: в центре $-1,3 \mathrm{~cm}$, по краям - 1,7-1.8 см; толщина в центре (вместе с рукоятью) - 2,5 см. Клинок: длина: от середины перекрестья 24,2 см, от краев перекрестья - 23,0 см; ширина: у перекрестья - 5,1 см, в середине 4,1 см; толщина: у перекрестья - 0,8 см, в середине $-0,6$ см.

2. Кинжал из окрестностей с. Кундpaвы (рис. 2,2). Общая длина - 15,5 см. Навершие: длина 6,8 см; ширина: в середине 1,0 см, на концах - 0,9-1,0 см; толщина: в середине $-1,4$ см, на концах $-1,1-1,2$ см. Валик: длина $-2,1$ см; ширина $-0,3$ см. Рукоять: длина $-7,9$ см; ширина: у перекрестья $-3,0$ см, в середине $-2,8$ см, у валика $-2,1$ см; толщина: у перекрестья $-1,1$ см, в середине $-1,6$ см, у валика - 1,2 см. Перекрестье: длина $-6,4$ см; ширина: в середине - 1,2 см, по краям - 1,4 см; толщина: в середине (вместе с рукоятью) 2,5 см; по краям - 0,5 см. Клинок: ширина: у перекрестья - 4,2 см, на месте слома - 2,8 см; толщина: у перекрестья - 0,8 см, на месте слома - 0,4 см.

3. Кинжал из окрестностей с. Дубровка (рис. 2,3). Общая длина - 38,3 см. Навершие: длина - 4,6 см; ширина - 0,6-0,7 см; толщина $-0,6-0,7$ см. Рукоять: длина $-8,5$ см, ширина: у навершия - 1,3 см, у перекрестья 1,6 см; толщина - 1,0 см. Перекрестье: длина - 7,2 см; ширина $-0,7-1,0$ см; толщина в центре $-1,5 \mathrm{~cm}$; по краям - 0,3-0,4 см. Клинок: длина - 26,2 см, ширина у перекрестья $4,1 \mathrm{~cm}$, толщина у перекрестья - 0,8 см.

\section{ПРИМЕЧАНИЕ}

\footnotetext{
${ }^{1}$ Исследование выполнено при финансовой поддержке Министерства образования и науки Российской Федерации (государственное задание 33.5494.2017/БЧ).

The work was supported by the Ministry of Education and Science of the Russian Federation (state task 33.5494.2017/ Б4).
} 


\section{ИЛЛЮСТРАЦИИ}

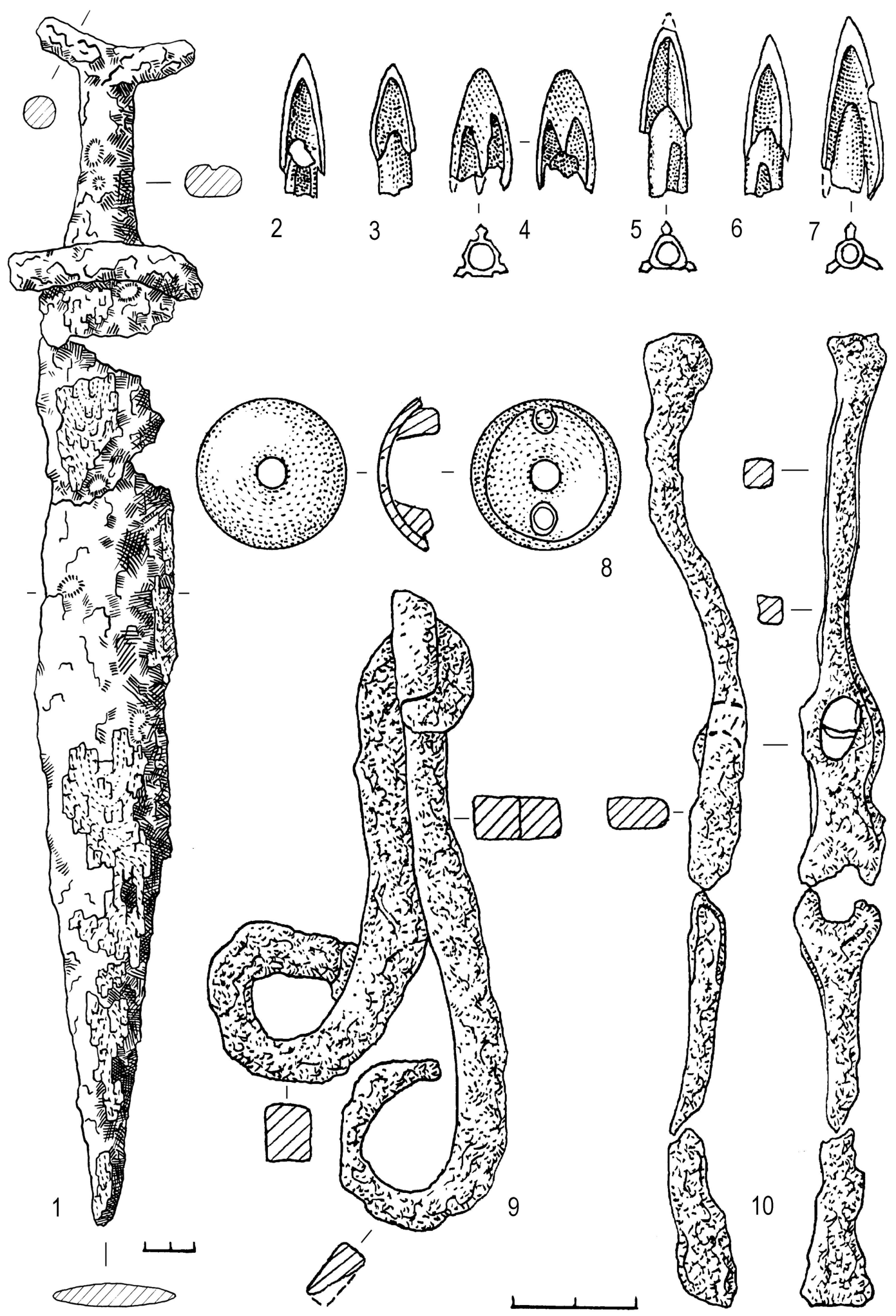

Рис. 1. Инвентарь из погребения на территории профтехучилища (Училище):

1, 9, 10 - железо; 2-8 - бронза

Fig. 1. Grave goods from the burial on the territory of the vocational training school (Uchilishche): 1,9, 10 - iron; $2-8$ - bronze 


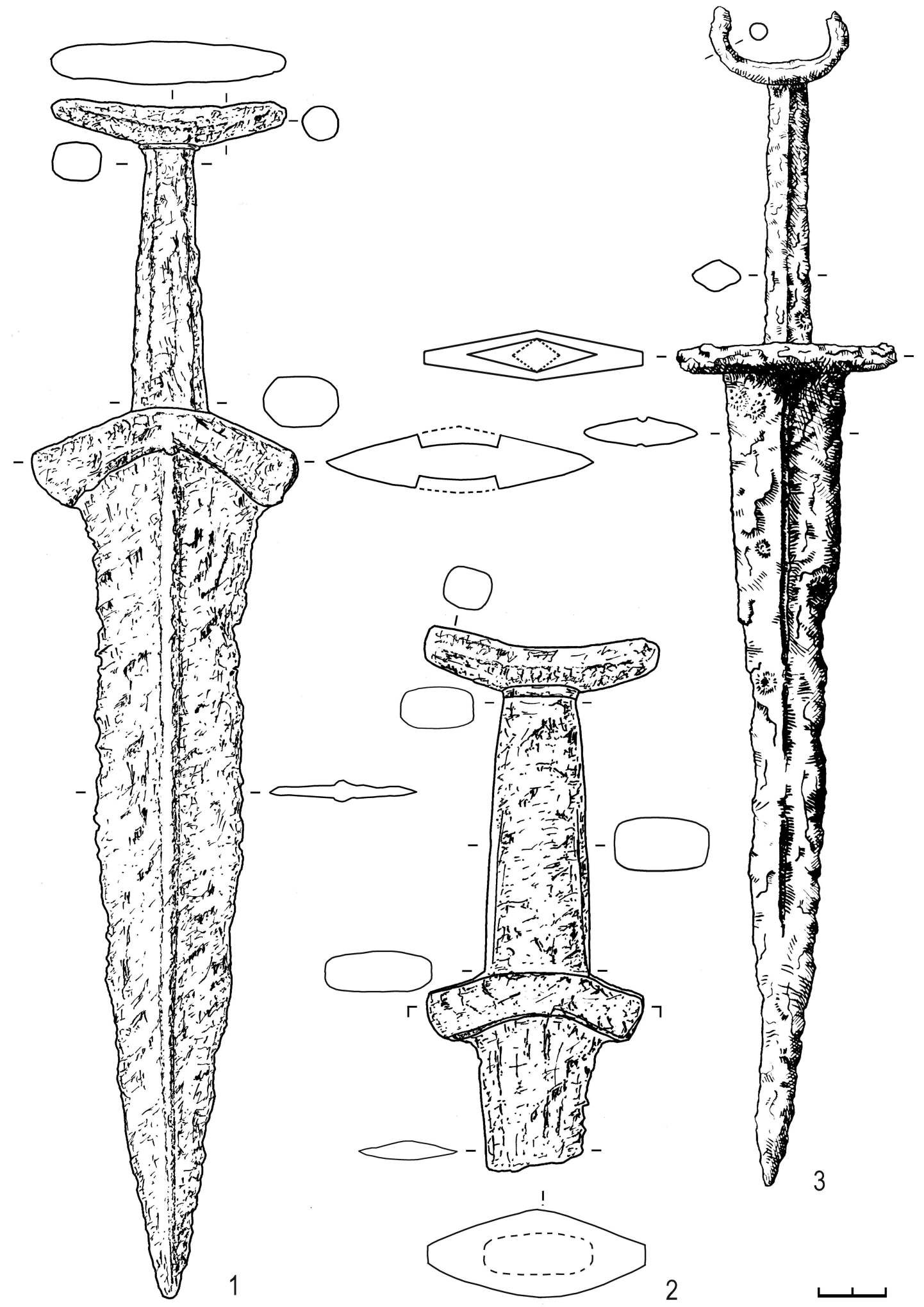

Рис. 2. Кинжалы раннесарматского времени Южного Зауралья:

1 - с. Боровое; 2 - с. Кундравы; 3 - с. Дубровка (1-3 - железо)

Fig. 2. Daggers of the early Sarmatian time of the Southern Trans-Urals:

1 - Borovoe village; 2 - Kundravy village; 3 - Dubrovka village (1-3 - iron) 


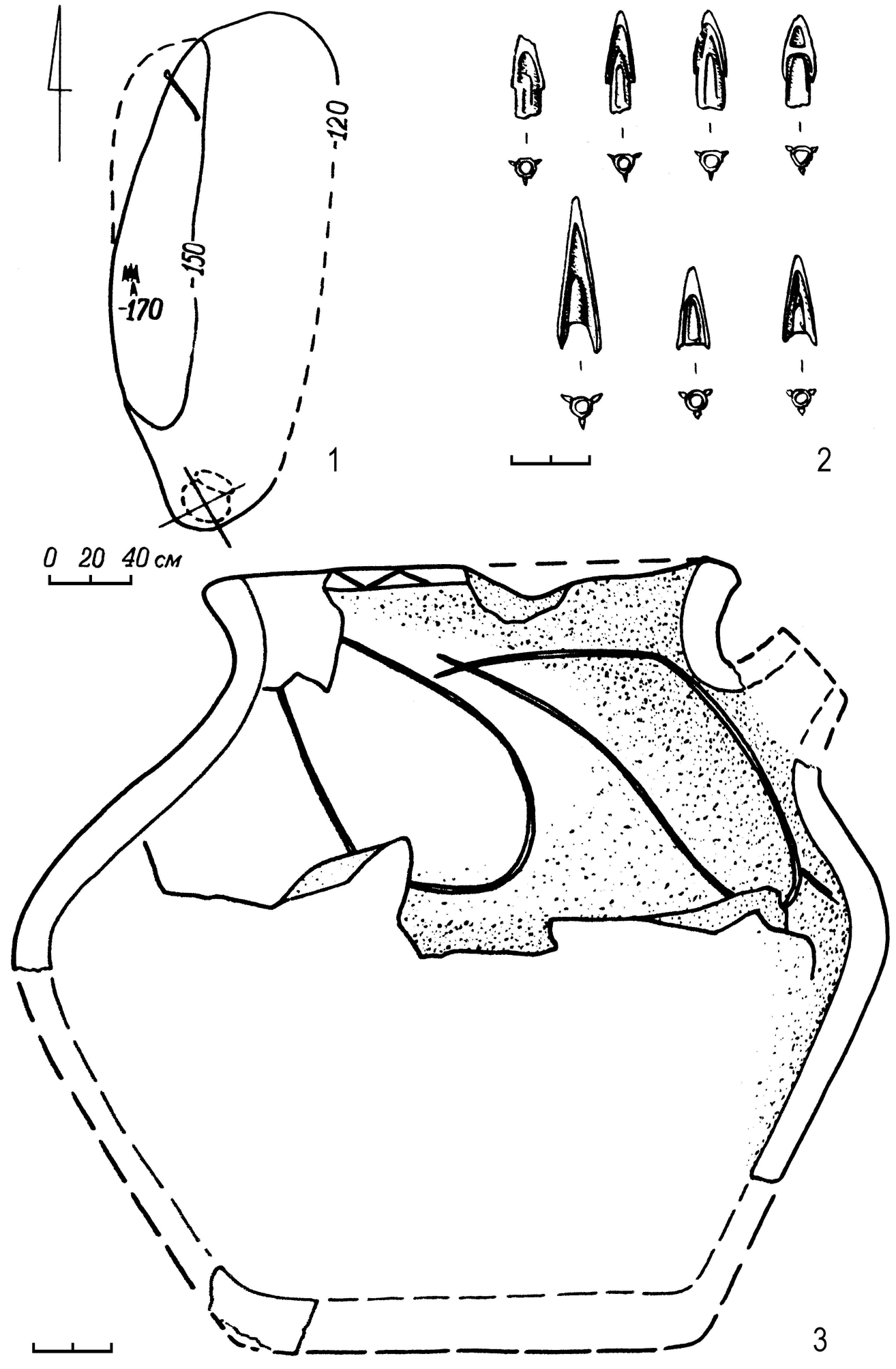

Рис. 3. Погребение у с. Могутовка:

1 - план могильной ямы; 2 - наконечники стрел; 3 - сосуд (2 - бронза; 3 - керамика)

Fig. 3. Burial near Mogutovka village:

1 - plan of the burial pit; 2 - arrowheads; 3 - vessel $(2$ - bronze; 3 - ceramic) 

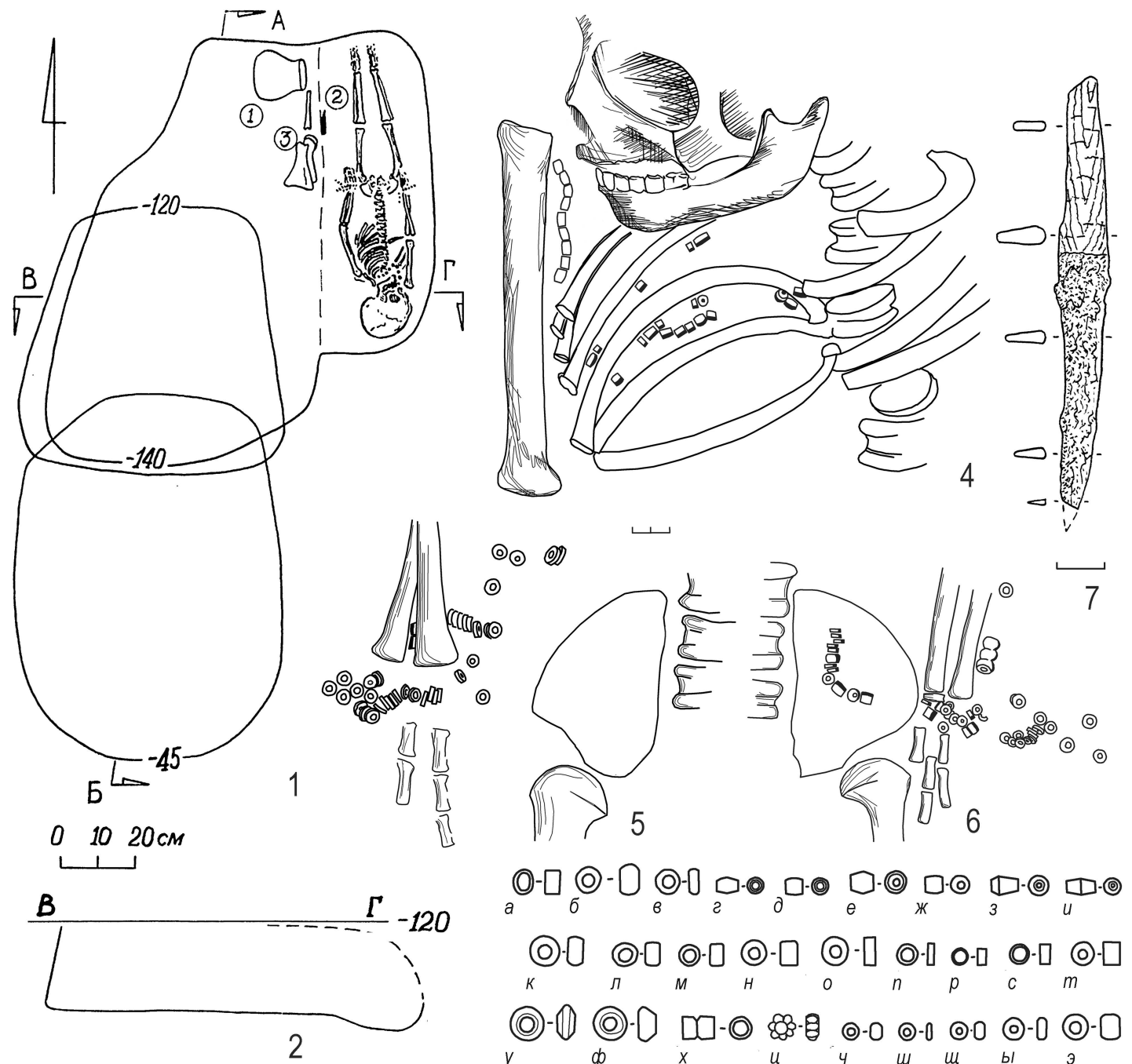

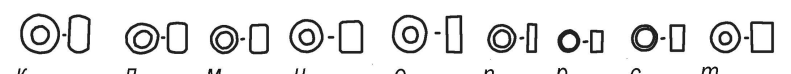

(ด)-(1) (๑)- y

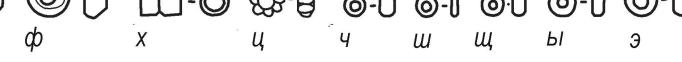

$\underline{E}$

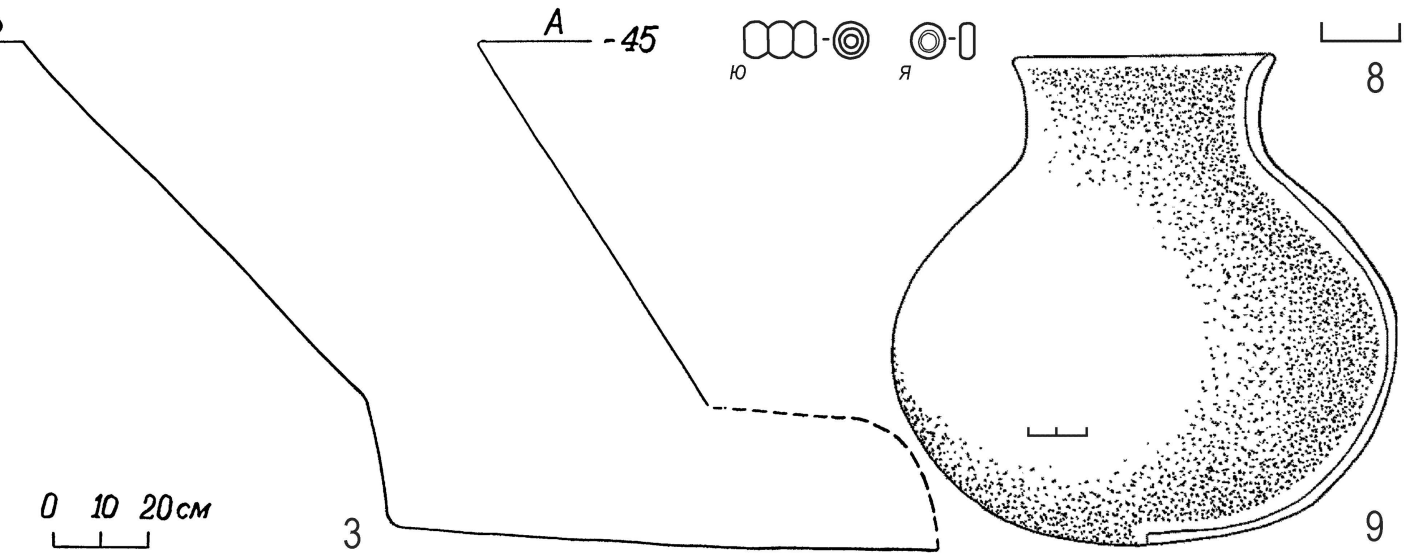

Рис. 4. Могильник Дружинский, курган 2, погребение 2:

1 - план могильной ямы (1 - сосуд; 2 - нож; 3 - кости барана); 2, 3 - разрезы могильной ямы; 4-6 - расположение бус и бисера на погребенном; 7 - нож; 8 - бусы и бисер;

9 - сосуд (7 - железо; 8 - стекло, паста, гагат; 9 - керамика)

Fig. 4. Druzhinskiy burial mound, barrow 2, burial 2:

1 - plan of the burial pit ( 1 - vessel; 2 - knife; 3 - sheep bones); 2, 3 - cross-section views of the burial pit;

$4-6$ - location of the beads on the buried; 7 - knife; 8 - beads;

9 - vessel $(7-$ iron; 8 - glass, paste, gagate; 9 - ceramic) 
A.D. Tairov. The Sites of the Early Nomads on the North-East Periphery of the Sarmatian World

\section{СПИСОК ЛИТЕРАТУРЫ}

Акишев К. А., Кушаев Г. А., 1963. Древняя культура саков и усуней долины реки Или. Алма-Ата : Изд-во АН КазССР. 321 с.

Алексеева Е. М., 1978. Античные бусы Северного Причерноморья. М. : Наука. 105 с.

Белицкий А. В., 2013. О происхождении и распространении мечей с дуговидным навершием и перекрестием // Археология Восточно-Европейской степи. Вып. 10. Саратов : Изд-во СГУ. C. 230-234.

Боталов С. Г., 1986. Исследование Дружинского могильника Варненского района Челябинской области в 1986 г. Отчет // Архив заповедника «Аркаим». Ф. Р-1. Д. 87.

Боталов С. Г., Гуцалов С. Ю., 2000. Гунно-сарматы Урало-Казахстанских степей. Челябинск : Рифей. $266 \mathrm{c}$.

Васильев В. Н., 2001. Вооружение и военное дело кочевников Южного Урала в VI-II вв. до нашей эры. Уфа: Гилем. $153 \mathrm{c}$.

Васильев В. Н., 2004. К хронологии раннепрохоровского комплекса // Уфимский археологический вестник. Вып. 5. С. 153-172.

Васильев В. Н., Сиротин С. В., 2004. Ново-Мусинский 3 курган // Уфимский археологический вестник. Вып. 5. С. 173-180.

Глебов В. П., Житников В.Г., 2008. Раннесарматские погребения с мечами переходного типа в Нижнем Подонье // Труды археологического научно-исследовательского бюро. Т. III. Ростов н/Д. С. 104-111.

Денисов А. В., 2018. Древние мечи из фондов Ульяновского областного краеведческого музея им. И. А. Гончарова (УОКМ) // Краеведческие записки. Вып. 16. Ульяновск : Корпорация технологий продвижения. С. 376-381.

Исмагилов Р. Б., 2001. Клинковое оружие эпохи ранних кочевников из Южного Приуралья (случайные находки) // Уфимский археологический вестник. Вып. 3. С. 117-147.

Мошкова М. Г., 1963. Памятники прохоровской культуры. М. : Изд-во АН СССР. 54 с. (Свод археологических источников ; вып. Д1-10).

Мошкова М. Г., 1969. Погребения VI-IV вв. до н. э. в Челябинской группе курганов // Древности Восточной Европы. М. : Наука. С. 138-147.

Обыденнов М. Ф., Савельев Н. С., 1994. Оружие ранних кочевников: новые находки в Башкортостане // Вооружение и военное дело древних племен Южного Урала. Уфа : ПКФ «КонкордИнвест». С. 100-115.

Скрипкин А. С., Ким М. Г., 2013. Новоузенские курганы (к проблеме миграции южноуральских кочевников в Нижнее Поволжье в IV веке до н. э.)
// Археология Восточно-Европейской степи. Саратов. Вып. 10. С. 271-280.

Смирнов К. Ф., 1961. Вооружение савроматов // Материалы и исследования по археологии СССР. № 101. М. : Изд-во АН СССР. 162 c.

Смирнов К. Ф., 1964. Савроматы. Ранняя история и культура сармат. М. : Наука. 380 с.

Смирнов К. Ф., 1975. Сарматы на Илеке. М. : Наука. $176 \mathrm{c}$.

Соколов П. М., 2013. К проблеме типологии и хронологии савроматского клинкового оружия // Археология Восточно-Европейской степи. Вып. 10. Саратов. С. 281-287.

Таиров А. Д., 1987. Памятники раннего железного века в окрестностях Челябинска // Седьмые Бирюковские чтения, посвященные 250-летию Челябинска : тезисы докладов. Челябинск. С. 6-8.

Таиров А. Д., 2016. К вопросу об истоках форм раннесарматского клинкового оружия // Актуальные проблемы археологии Евразии. Алматы : Институт археологии им. А. Х. Маргулана. C. 332-344.

Хабдулина М. К., Малютина Т. С., 1982. Погребальный комплекс V-IV вв. до н. э. из Челябинской области // Краткие сообщения Института археологии. Вып. 170. С. 73-80.

Хабдулина М. К., Малютина Т. С., Виноградов Н. Б., 1980. Разрушенное погребение и случайные находки раннего железного века в г. Челябинске и Челябинской области // Архив ИА PAН. Р-I. № 7706. Полевые археологические исследования Урало-Казахстанской археологической экспедиции в 1979 году. Т. 1. Челябинск.

\section{REFERENCES}

Akishev K. A., Kushaev G.A., 1963. Ancient culture of Sakas and Wusun of the Ili River Valley. AlmaAta, Academy of Sciences of the KazSSR. 321 p. (in Russian).

Alekseeva E.M., 1978. Ancient beads of the North Pontic Region. Moscow, Nauka Publ. 105 p. (in Russian).

Belickiy A.V., 2013. Anent origin and distribution of the swords with arcuate pommel and crossguard. Arkheologiya Vostochno-Evropeyskoy stepi, iss. 10. Saratov, pp. 230-234. (in Russian).

Botalov S.G., 1986. Investigation of the Druzhinskiy burial ground on the territory of the Varna district, Chelyabinsk Oblast in the 1986. Report. Arkhiv zapovednika «Arkaim», fond R-1, delo no. 87. (in Russian).

Botalov S.G., Gutsalov S.Yu., 2000. Hunno-Sarmatian Tribes of the Ural-Kazakhstan Steppes. Chelyabinsk, Rifey Publ. 266 p. (in Russian). 
Vasilyev V.N., 2001. Arms and military business of nomads of the Southern Ural in the $6^{\text {th }}-2^{\text {nd }}$ centuries BC. Ufa, Gilem Publ. 153 p. (in Russian).

Vasilyev V.N., 2004. Anent the chronology of the Early Prochorovskiy complex. Ufimskiy archeologicheskiy vestnik, iss. 5, pp. 153-172. (in Russian).

Vasilyev V.N., Sirotin S.V., 2004. Kurgan NovoMusinskiy 3. Ufimskiy archeologicheskiy vestnik, iss. 5, pp. 173-180. (in Russian).

Glebov V.P., Gitnikov V.G., 2008. Early Sarmatian burials with the swords of the transition period in the Lower Don. Trudy arkheologicheskogo nauchno-issledovatel'skogo byuro, vol. III. Rostov-on-Don, pp. 104-111.

Denisov A.V., 2018. Ancient swords from the collections of Ulyanovsk regional local history museum n. a. I. A. Goncharov. Krayevedcheskiye zapiski, iss. 16. Ulyanovsk, Advance Technology Corporation Publishing House, pp. 376-381. (in Russian).

Ismagilov R.B., 2001. Bladed weapons of the Early Nomads from the Southern Cis-Urals (accidental finds). Ufimskiy archeologicheskiy vestnik, iss. 3. Ufa, pp. 117-147. (in Russian).

Moshkova M.G., 1963. Monuments of Prokhorov culture, iss. D1-10, Moscow, AS USSR. 54 p. (in Russian).

Moshkova M.G., 1969. Burials from the sixth to forth centuries BC in the Chelyabinsk kurgan group. Drevnosti Vostochnoy Yevropy. Moscow, Nauka Publ., pp. 138-147. (in Russian).

Obidennov M.F., Savelyev N.S., 1994. Weapons of the Early Nomads: new finds in the Bashkortostan. Vooruzheniye $i$ voyennoye delo drevnikh plemen Yuzhnogo Urala. Ufa, Concord-Invest PKF Publ., pp. 100-115. (in Russian).

Skripkin A.S., Kim M.G., 2013. Novouzenskie kurgans (to the problem of Southern Urals nomads migration to the Lower Volga region in the fourth century BC.). Arkheologiya VostochnoEvropeyskoy stepi, iss. 10. Saratov, pp. 271-280. (in Russian).

Smirnov K.F., 1961. Armament of the Sauromats. Materials and research on archaeology of the USSR, no. 101. Moscow, AS USSR Publ. 162 p. (in Russian).

Smirnov K.F., 1964. Sauromats. Early history and culture of Sarmatians. Moscow, Nauka Publ. 380 p. (in Russian).

Smirnov K. F., 1975. Sarmatians on the Ilek river. Moscow, Nauka Publ. 176 p. (in Russian).

Sokolov P.M., 2013. To the problem of typology and chronology of the sauromatian bladed weapons. Arkheologiya Vostochno-Evropeyskoy stepi, iss. 10, Saratov, pp. 281-287. (in Russian).

Tairov A.D., 1987. Site of the Early Iron Age in the vicinity of Chelyabinsk. Sed'myye Biryukovskiye chteniya posvyashchennyye 250-letiyu Chelyabinska. Tezisy dokladov. Chelyabinsk, pp. 6-8. (in Russian).

Tairov A.D., 2016. To the origin issue of the forms of Early Sarmatian bladed weapons. Aktual'nyye problemy arkheologii Yevrazii. Almaty, Institute of Archeology named after A. Kh. Margulan, pp. 332-344. (in Russian).

Khabdulina M.K., Malyutina T.S., 1982. Burial ground from the fifth to fourth centuries BC from Chelyabinsk region. Brief communications of the Institute of archaeology, iss. 170, pp. 73-80. (in Russian).

Khabdulina M.K., Malyutina T.S., Vinogradov N.B., 1980. Ruined burial and accidental finds of the Early Iron Age in Chelyabinsk and Chelyabinsk Oblast. Arkhiv IA RAN, R-1, no. 7706. Polevyye arkheologicheskiye issledovaniya UraloKazakhstanskoy arkheologicheskoy ekspeditsii v 1979 godu, vol. 1. Chelyabinsk. (in Russian).

\section{Information about the Author}

Aleksander D. Tairov, Doctor of Sciences (History), Director of the Eurasian Studies Research and Education Centre, South Ural State University (National Research University), Prosp. Lenina, 76, 454080 Chelyabinsk, Russian Federation, tairov55@mail.ru, https://orcid.org/0000-0001-8575-0430

\section{Информация об авторе}

Александр Дмитриевич Таиров, доктор исторических наук, директор Научно-образовательного центра евразийских исследований, Южно-Уральский государственный университет (национальный исследовательский университет), просп. Ленина, 76, 454080 г. Челябинск, Российская Федерация, tairov55@mail.ru, https://orcid.org/0000-0001-8575-0430 